\section{Nitrogen Uptake and Use Efficiency in Sweet Basil Production under Low Tunnels}

\author{
Tej P. Acharya, Mark S. Reiter, and Greg Welbaum \\ School of Plant and Environmental Sciences, 330 Smyth Hall, Virginia Tech, \\ Blacksburg, VA 24061
}

\section{Ramón A. Arancibia \\ University of Missouri Extension, WC region, $1 \mathrm{~N}$ Delaware Street, Butler, MO 64730}

Additional index words. apparent $\mathrm{N}$ recovery efficiency, fertilization, nitrogen use efficiency, Ocimum basilicum, rowcover

\begin{abstract}
Low tunnels (LTs) enhance vegetative growth and production in comparison with open field, but it is not known whether nitrogen $(N)$ requirements and use efficiency increase or decrease for optimal crop performance. Therefore, the purpose of this study was to determine differences in $\mathrm{N}$ requirement, uptake, and use efficiency in basil grown under LTs compared with open field. The experimental design each year was a split plot with four replications. The main effect (plots) was $\mathbf{N}$ fertilizer application rate $(0,37,74$, 111,148 , and $185 \mathrm{~kg} \cdot \mathrm{ha}^{-1}$ ) and the secondary effect (subplots) was production system (LTs covered with spun-bonded rowcover vs. open field). Plant height and stem diameter were greater under LT than open field; however, they were unaffected by $\mathbf{N}$ fertilizer rate. Total fresh and dry weight increased with LT by $61 \%$ and $58 \%$ and by $50 \%$ and $48 \%$ in 2017 and 2018 , respectively. Optimum $N$ rates for fresh weight $(98 \%$ of peak yield) were 124 and $104 \mathrm{~kg} \cdot \mathrm{ha}^{-1} \mathrm{~N}$ under LT and open field, respectively. Leaf $\mathrm{N}$ concentration decreased under LT, but total plant $N$ uptake increased because of increased dry weight. Without fertilization, soil available $\mathbf{N}$ use efficiency (SNUE) for dry weight increased by $45 \%$ and $66 \%$ in 2017 and 2018, respectively. Mixed results were obtained for $\mathbf{N}$ fertilizer use efficiency (NFUE) in response to $\mathrm{N}$ rate. In conclusion, $\mathrm{LT}$ increased summer production of sweet basil, total plant $\mathrm{N}$ uptake, and SNUE.
\end{abstract}

Protected production systems such as LTs and high tunnels increase temperatures and extend the growing seasons earlier in spring or later in fall (Lamont, 2005). However, protected systems may also enhance vegetative growth and increase productivity of warm-season vegetable crops in summer (Arancibia, 2012). Spun-bonded rowcovers used as LTs or as unsupported floating blankets create a greenhouse effect by modifying the microenvironment, which reduces evapo-

Received for publication 30 Aug. 2019. Accepted for publication 13 Dec. 2019.

Published online 27 February 2020.

This project is supported by the National Institute of Food and Agriculture, U.S. Department of Agriculture (USDA), under award number 2015-38640-23780 through the Southern Sustainable Agriculture Research and Education (SARE) program under subaward number LS16-268. Any opinions, findings, conclusions, or recommendations expressed in this publication are those of the author(s) and do not necessarily reflect the view of the USDA or SARE. USDA is an equal opportunity employer and service provider.

T.P.A. is a Graduate Research Assistant.

R.A.A. is the corresponding author. E-mail: raa522@missouri.edu.

This is an open access article distributed under the CC BY-NC-ND license (https://creativecommons. org/licenses/by-nc-nd/4.0/). purposes either as a fresh or dried spice (Simon et al., 1990). Fresh basil is marketed as either rooted plant in pots or as detached leaves. Basil production in the United States has increased significantly in recent years due to rising consumer demand, thus benefiting vegetable and herb growers (DeKalb et al., 2014; Wyenandt et al., 2015). Approximately 4400 ha of basil were grown in the United States in 2010, but this production did not fulfill demand (Wyenandt et al., 2015). Approximately $20 \%$ (US\$60 million) of fresh sweet basil was imported from Colombia, Israel, Mexico, and Peru. However, importing basil from other countries is challenging because of disease and pest issues coupled with shipping cost (Wyenandt et al., 2015). Therefore, marketing basil from domestic growers is preferable. Hence, there is potential to increase domestic sweet basil production to meet the growing demand for quality product. Basil production under LTs may extend the production season and increase yield resulting in improved sustainability of small specialty crop growers.

Vegetable farmers use LTs as protected systems in early spring, but there is little to no information on growth and production during the summer or optimal nutrient needs to sustain the enhanced growth and production under LTs. Possible interactions between LTs and $\mathrm{N}$ may occur and needs further investigation. We postulated that 1) because LT consistently enhances plant growth, $\mathrm{N}$ utilization would be more efficient in comparison with conventional open field production systems; and 2) crops grown under LTs require more $\mathrm{N}$ to sustain greater biomass production. Therefore, the objectives of this study were 1) to compare growth and production parameters of basil grown under LTs and open field to determine differences in SNUE, and 2) to determine differences in optimal $\mathrm{N}$ application rate, $\mathrm{N}$ uptake, NFUE, and ANRE between LTs and open field. SNUE is an estimation of the marketable yield and/or biomass produced by a unit of $\mathrm{N}$ available in the soil. The yield or biomass produced in response to a unit of $\mathrm{N}$ fertilizer corresponds to NFUE. Similarly, ANRE is the efficiency of the plant to uptake the applied $\mathrm{N}$ fertilizer under the growing conditions.

\section{Materials and Methods}

This study was conducted at the Eastern Shore Agricultural Research and Extension Center-Virginia Tech in Painter, VA (lat. $37.58466^{\circ} \mathrm{N}$, long. $75.82114^{\circ} \mathrm{W}$ ). Experiments were conducted in the summer of 2017 and 2018. Soil type is Bojac sandy loam (thermic Typic Hapludults) with 59\% sand, $30 \%$ silt, and $11 \%$ clay in the Ap (plowed A) horizon (0-46 cm) (Fleming et al., 2013).

Experimental design. Each year, the experimental design was a split plot with four replications. The main effect (plots) was $\mathrm{N}$ rate at 0 , 37, 74, 111, 148, and $185 \mathrm{~kg} \cdot \mathrm{ha}^{-1}$, and the secondary effect (subplots) was production system: LT covered with spun-bonded rowcover 
(33.8 g.m ${ }^{-2}$; Dewitt, Sikeston, MO) and open field. Nitrogen rates were $0,0.33$, $0.67,1,1.33$, and 1.67 times the recommended $\mathrm{N}$ application $\left(111 \mathrm{~kg} \cdot \mathrm{ha}^{-1}\right)$ for basil in the southeastern United States (Kemble, 2016). Field consisted of 13 rows $60 \mathrm{~m}$ long and $1.8 \mathrm{~m}$ apart (center to center). There were six record rows and seven guard rows: one guard row between record rows and one at each border. Field was divided into four 15-m-long blocks (replication) and in each block, $\mathrm{N}$ rate was randomly assigned to record rows (plots). Within each plot, there were two 6-m-long subplots separated by a $1.5-\mathrm{m}$ alley. Production systems (LT and open field) were allocated randomly to each subplot.

Soil test and fertilization. Four soil samples (one from each block) were collected from the top $15 \mathrm{~cm}$ before fertilizer application and field preparation, and submitted to a private laboratory for analysis both years. Based on soil test results indicating that $\mathrm{K}$ and $\mathrm{Ca}$ were below optimum levels (Wyenandt, 2016), potassium sulfate and gypsum were broadcasted at a rate of 93 $\mathrm{kg} \cdot \mathrm{ha}^{-1} \mathrm{~K}$ and $52 \mathrm{~kg} \cdot \mathrm{ha}^{-1} \mathrm{Ca}$, respectively. Then, urea $(46 \% \mathrm{~N})$ was applied to each plot at the corresponding $\mathrm{N}$ rate treatment and thoroughly mixed into the soil with a rototiller. In addition, soil test included extractable nitrate-N, which was used to determine soil available $\mathrm{N}$ in the top $15 \mathrm{~cm}$ before $\mathrm{N}$ fertilization.

Field preparation and planting. The research field was conventionally tilled. All fertilizers were applied and incorporated before raising the beds and laying drip irrigation tape (Aqua Trax, El Cajon, CA) and black plastic mulch (Hilex Poly Co., North Vernon, IN). Five-week-old (13- to $15-\mathrm{cm}$ tall) 'Eleonora' sweet basil seedlings were hand planted into single row beds on 3 May 2017 and 25 May 2018. Between- and in-row plant spacing were 1.8 and $0.6 \mathrm{~m}$, respectively, corresponding to a population density of 9260 plants/ha. LTs were installed after planting and supported by 3-m-long polyvinyl chloride hoops bent to form a $1.0-\mathrm{m}$ tall and $1.0-\mathrm{m}$ wide tunnel covered with spun-bonded rowcover held in place with 1.5 to $2.0 \mathrm{~kg}$ sandbags on the sides. All other cultural practices besides $\mathrm{N}$ fertilizer were according to the Southeastern U.S. Vegetable Crop Handbook (Kemble, 2016).

Plant production variables. Two middle plants per subplot were randomly selected and tagged to measure plant height, stem diameter, fresh weight (FW), and dry weight (DW). Hence, a total of eight plants were selected for each production system and $\mathrm{N}$ rate. Plant variables were measured at each harvest determined by initial development of the inflorescence. Plant height was measured from the plant base to the top of the stem in the first three harvests. Stem diameter was measured at the base of the plant by using a Vernier micrometer in the first two harvests.

In 2017, tagged plants were harvested five times, at 30,60, 85, 101, and $123 \mathrm{~d}$ after transplanting (DAT), and in 2018, plants were harvested four times, at 30, 52, 75, and 99 DAT. At first harvest, plants were cut 20 and $25 \mathrm{~cm}$ aboveground in the open field and LTs, respectively. Plants were taller under LTs and it was necessary to leave similar foliage area as in the open field for further growth. In subsequent harvests, the newly grown shoots were carefully cut $2 \mathrm{~cm}$ above the base to allow regrowth for the next harvest. Plant FW was taken, and total plant material was dried at $70{ }^{\circ} \mathrm{C}$ for at least $15 \mathrm{~d}$ until a constant weight was achieved to determine plant DW at each harvest. Total plant DW was determined by the summation of plant DW from all harvests. Nontagged plants in record and guard rows were cut down to the same height as the tagged plants, with a reciprocating hedgerow trimmer at each harvest date. Dry plant tissue was also used to determine total plant $\mathrm{N}$ uptake.

Optimum $N$ rate. The optimum $\mathrm{N}$ fertilization rate was determined for each production system and year based on the relative yield for each $\mathrm{N}$ rate in relation to maximum yield (Hochmuth et al., 2017). The following formula was used: $\mathrm{RY}_{\mathrm{x}}(\%)=\mathrm{Y}_{\mathrm{x}} / \mathrm{Y}_{\mathrm{mx}} \times 100$, where $R Y$ is relative yield, $Y$ is yield at $x N$ rate, and $\mathrm{mx}$ refers to the maximum yield among replications. Then, the peak yield and its $\mathrm{N}$ rate were obtained from the first derivative $\left[\mathrm{F}^{\prime}(\mathrm{x})=0\right]$ of the regression equation. The optimum $\mathrm{N}$ rate was defined as the lowest $\mathrm{N}$ rate with yield $98 \%$ of the peak yield.

Nitrogen uptake and $N$ use efficiency. To determine leaf $\mathrm{N}$ concentration, 20 young fully expanded leaves were collected from all tagged and nontagged plants from each subplot at first, second, and third harvest in both years. Leaf samples were also dried at $70{ }^{\circ} \mathrm{C}$ for at least $15 \mathrm{~d}$. Dry leaf samples were ground to pass a 2-mm screen for $\mathrm{N}$ analysis. Similarly, dry tissue from each plant was ground entirely, and a sample was further ground to pass a 2-mm screen for $\mathrm{N}$ analysis to determine plant $\mathrm{N}$ uptake. The $\mathrm{N}$ concentration in each leaf and plant tissue was determined from a 10-mg sample by dry combustion using an Elementar cube (Vario EL cube; Elementar, Elementar Americas, Inc., Mt. Laurel, NJ) (Bremner, 1996). Plant $\mathrm{N}$ concentration was determined by averaging the concentration from all harvests. However, plant $\mathrm{N}$ uptake (aboveground tissue) was determined by multiplying plant $\mathrm{N}$ concentration by plant DW at each harvest. Then, total plant $\mathrm{N}$ uptake was determined by adding the plant $\mathrm{N}$ uptake from all harvests for each $\mathrm{N}$ treatment combination.

To determine SNUE for FW and DW, nitrate- $\mathrm{N}$ in a hectare was determined based on the soil nitrate-N content in the top $15 \mathrm{~cm}$ from the soil samples before $\mathrm{N}$ fertilization and soil bulk density $\left(1.4 \mathrm{~g} \cdot \mathrm{cm}^{-3}\right)$. The relative yield due to production system in relation to soil available $\mathrm{N}$ without fertilizer corresponds to SNUE and was determined by the following formula: $\mathrm{SNUE}=\mathrm{YieldN}_{0} /$ Soil available nitrate $\mathrm{N}_{0}$, where $\mathrm{N}_{0}$ corresponds to zero $\mathrm{N}$ fertilization (control). The relative yield increase (subtracting yield from the control without fertilization) in relation to the $\mathrm{N}$ rate is the NFUE and was determined by the following formula: $\operatorname{NFUE}_{\mathrm{x}}=\left(\mathrm{Y}_{\mathrm{x}}-\mathrm{Y}_{0}\right)$ / $\mathrm{N}_{\mathrm{x}}$, where $\mathrm{Y}$ is yield, $\mathrm{x}$ is the $\mathrm{N}$ rate, and 0 corresponds to zero $\mathrm{N}$ fertilization. The relative efficiency with which the plant uptake applied $\mathrm{N}$ fertilizer corresponds to ANRE and was determined by the following formula ( $\mathrm{Ye}$ et al., 2007): $\operatorname{ANRE}_{\mathrm{x}}=\left(\mathrm{U}_{\mathrm{x}}-\mathrm{U}_{0}\right) / \mathrm{N}_{\mathrm{x}} \times 100$, where $\mathrm{U}$ is total $\mathrm{N}$ uptake by the plant, $\mathrm{x}$ corresponds to $\mathrm{N}$ rate, and 0 corresponds to zero $\mathrm{N}$ fertilization.

Statistical analysis. Data for the different variables were analyzed by R-studio 2016 (R core 2016, Vienna, Austria). Because there were interactions between $\mathrm{N}$ rate and year, analysis of variance (ANOVA) of the model (spilt plot) was conducted for each year and used to evaluate the significance of each effect (production system and $\mathrm{N}$ rate) and their interaction. Replication was treated as a random factor. $\mathrm{N}$ rate and production system were treated as fixed factors. Finally, regression was conducted to determine the relationship of production variables with $\mathrm{N}$ rate.

\section{Results}

Plant growth and production. Data analyses were conducted for each year because there were interactions between $\mathrm{N}$ rate and year for production variables. For each year, no significant interaction were detected between $\mathrm{N}$ rate and production system for growth and yield. Plant growth (averaged across $\mathrm{N}$ rate) increased in sweet basil grown under LT in both years, except for stem diameter at 60 DAT in 2017 (Fig. 1). Stem diameter increased by an average of $27 \%$ at 30 DAT both years and $12 \%$ at 52 DAT in 2018. Plant height increased by an average of $42 \%$ in the first three harvests both years (Fig. 2). In contrast, plant height and stem diameter were the same among the $\mathrm{N}$ rate for all sampling dates.

Overall, LT increased basil FW and DW production (averaged across $\mathrm{N}$ rate) compared with open field in both years (Fig. 3, Table 1). Figure 3 shows the linear pattern of cumulative FW harvest during the growing season for $111 \mathrm{~kg} \cdot \mathrm{ha}^{-1} \mathrm{~N}$ application rate in 2017 and 2018 (data pooled together). $\mathrm{Cu}$ mulative FW yield under LT increased at a faster rate than open field. The patterns of cumulative FW and DW yields were similar for all $\mathrm{N}$ rates in both years (data not presented). Overall, LT increased total yield of fresh basil by an average of $58 \%$ in comparison with open field for both years, and total DW production by $53 \%$ (Table 1 ). Nitrogen rate also influenced total plant FW in both years. Total FW increased in a linear $(P<0.001)$ and quadratic $(P<0.01)$ relationship with $\mathrm{N}$ rate under both LT and open field in 2017 and 2018, respectively (Table 1). Similarly, total plant DW production responded to $\mathrm{N}$ rate in a similar pattern as FW in both years (Table 1).

The optimum $\mathrm{N}$ rate for basil was $19 \%$ and $12 \%$ higher for LT than open field for FW and DW, respectively, as determined by the 


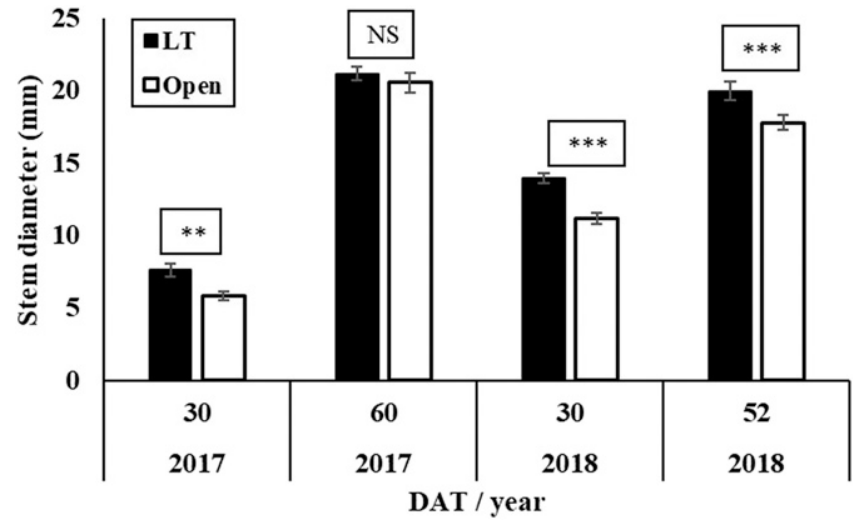

Fig. 1. Stem diameter in sweet basil grown under two production systems [low tunnel (LT) and open field (Open)]. DAT $=$ days after transplanting. Means are from all six $\mathrm{N}$ rate data $(\mathrm{n}=24)$. Bars in each column are the SE. NS, $* *, * * *$ Nonsignificant or significantly different by least significant difference at $P<0.01$ or 0.001 , respectively.

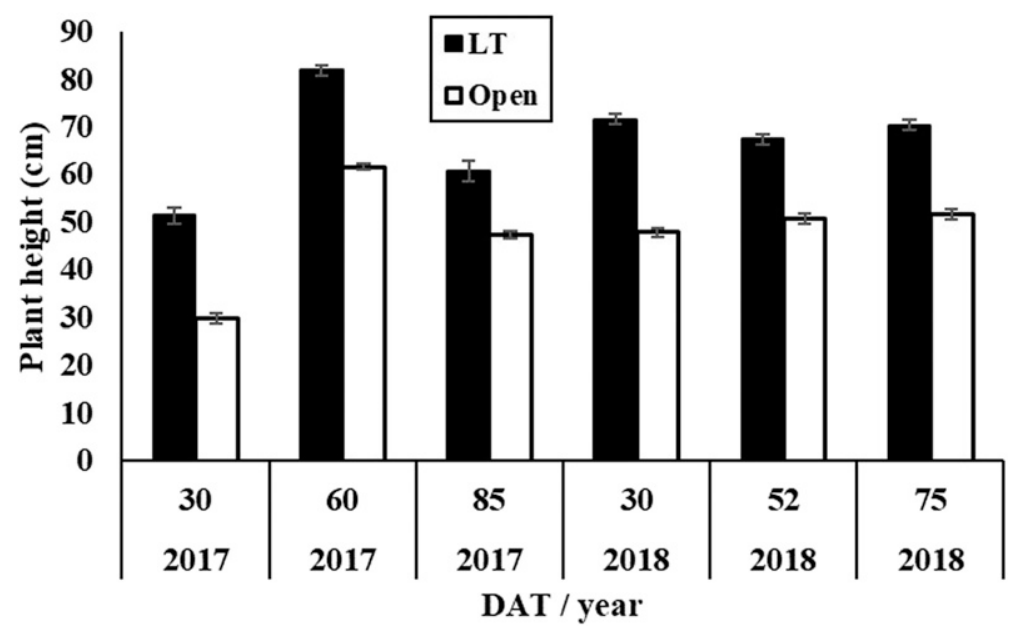

Fig. 2. Plant height in sweet basil grown under two production systems [low tunnel (LT) and open field (Open)]. DAT $=$ days after transplanting. Means are from all six $\mathrm{N}$ rate data $(\mathrm{n}=24)$. Bars in each column are the SE. $* * *$ Significantly different by least significant difference at $P<0.001$.

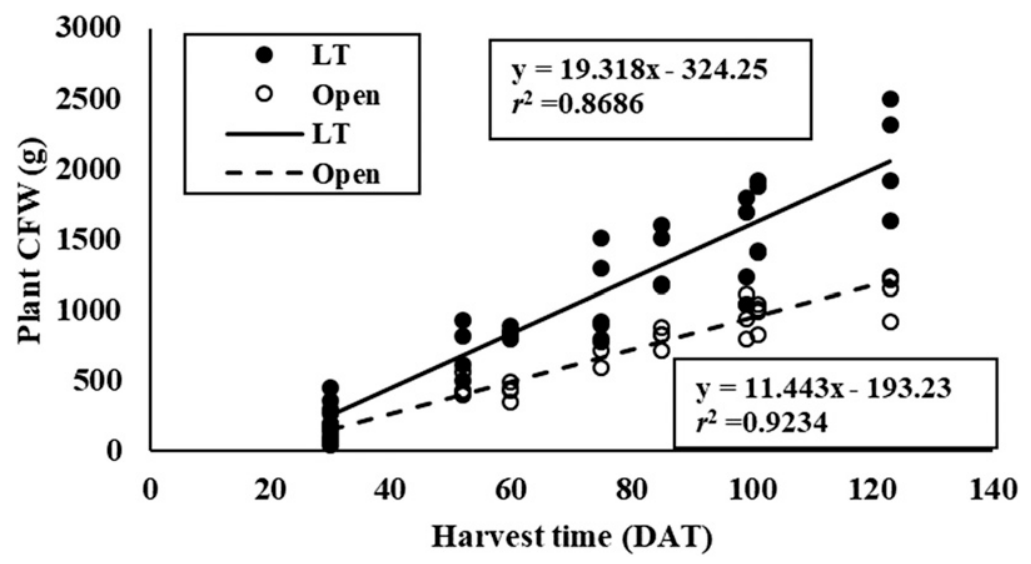

Fig. 3. Cumulative fresh weight (CFW) harvested throughout the season from sweet basil grown under two production systems [low tunnel (LT) and open field (Open)] at $111 \mathrm{~kg} \cdot \mathrm{ha}^{-1} \mathrm{~N}$ application rate. Data points are actual values from 2017 and 2018. DAT $=$ days after transplanting; $r^{2}=$ coefficient of determination.

lowest $\mathrm{N}$ rate at which yield was $98 \%$ of the peak yield. Relative FW increased in a quadratic relationship with $\mathrm{N}$ rate for LT and open field with peak yields at 161 and 141 $\mathrm{kg} \cdot \mathrm{ha}^{-1} \mathrm{~N}$ rate, respectively (Fig. 4). Optimum $\mathrm{N}$ rates were 124 and $104 \mathrm{~kg} \cdot \mathrm{ha}^{-1} \mathrm{~N}$ for LT and open field, respectively. Similar patterns were found for the relative DW (data not presented) and the optimal $\mathrm{N}$ rates were 118 and $105 \mathrm{~kg} \cdot \mathrm{ha}^{-1} \mathrm{~N}$ for LT and open field, respectively.

Leaf $N$ concentration and plant $N$ uptake. Overall, there were no significant interactions between $\mathrm{N}$ rate and production system for all variables each year, except for plant $\mathrm{N}$ concentration in 2018. Nitrogen concentration in leaves ranged from $2.5 \%$ to $5.6 \%$ and the overall average was $4.0 \%$ and $4.8 \%$ under the LT and open field conditions, respectively. LTs decreased leaf $\mathrm{N}$ concentration (averaged across $\mathrm{N}$ rate) in all three sampling dates in comparison with open field by an average of $18.7 \%$ and $16.3 \%$ in 2017 and 2018 , respectively (Table 2). In contrast, differences in leaf $\mathrm{N}$ concentration in response to $\mathrm{N}$ rate were not consistent. Although there were no differences due to $\mathrm{N}$ rate in the first harvest in both years, leaf $\mathrm{N}$ concentration in the second harvest in 2017 under the LT and open field increased in a linear and quadratic relationship, respectively. In the third harvest, both LT and open field responses were quadratic (Table 2). In 2018, however, N content increased linearly under the LT in the second and third harvests, but there was no response for open field (Table 2).

LTs also decreased plant $\mathrm{N}$ concentration (averaged across harvests and $\mathrm{N}$ rate) by $12 \%$ in 2017, but there was an interaction in 2018 (Table 3). Plant $\mathrm{N}$ under LT in 2018 decreased for all $\mathrm{N}$ rates except at $185 \mathrm{~kg} \cdot \mathrm{ha}^{-1}$. Nitrogen concentration in plant samples ranged from $3.6 \%$ to $6.0 \%$, and the overall average was $4.3 \%$ and $4.9 \%$ under LT and open field, respectively. The plant $\mathrm{N}$ concentration increased linearly with $\mathrm{N}$ rate for both LT and open field in 2017. In 2018, however, there were no differences in plant $\mathrm{N}$ concentration among $\mathrm{N}$ rate under either LT or open field.

Total plant $\mathrm{N}$ uptake (aboveground tissue) increased in basil grown under LTs compared with open field (Table 3). Total plant $\mathrm{N}$ uptake was estimated by unit area and ranged from 34.3 to $68.5 \mathrm{~kg} \cdot \mathrm{ha}^{-1}$ in both years, and for LT and open field were (averaged across $\mathrm{N}$ rate) 62.0 and $43.5 \mathrm{~kg} \cdot \mathrm{ha}^{-1}$, respectively, in 2017 , and 54.6 and $41.6 \mathrm{~kg} \cdot \mathrm{ha}^{-1}$, respectively, in 2018. Therefore, LT increased total plant $\mathrm{N}$ uptake in basil by $43 \%$ and $31 \%$ in 2017 and 2018, respectively. Similar to FW and DW production, plant $\mathrm{N}$ uptake increased in a linear relationship in 2017 and quadratic in 2018.

SNUE, NFUE, and ANRE. Under LT, SNUE for basil growth and production increased in comparison with open field in both years (Fig. 5). For FW, the overall SNUE average from both years was $226.5 \mathrm{~g} \cdot \mathrm{g}^{-1}$ soil nitrate-N under LT and $152.5 \mathrm{~g} \cdot \mathrm{g}^{-1}$ soil nitrate- $\mathrm{N}$ in open field, which corresponds to an increase of $48 \%$. Similarly, SNUE for DW was $24.9 \mathrm{~g} \cdot \mathrm{g}^{-1}$ soil nitrate-N under LT and $16.3 \mathrm{~g} \cdot \mathrm{g}^{-1}$ soil nitrate- $\mathrm{N}$ in open field, which correspond to an increase of $53 \%$ without $\mathrm{N}$ fertilizer application.

Both FW and DW NFUE responded inconsistently to LT treatment (averaged across $\mathrm{N}$ rates) (Table 4). For FW, NFUE ranged 
Table 1. Yield of sweet basil grown under two production systems (PS) [low tunnel (LT) and open field (Open)] at increasing N application rates.

\begin{tabular}{|c|c|c|c|c|c|c|c|c|}
\hline \multirow[b]{3}{*}{$\mathrm{N}$ rate $\left(\mathrm{kg} \cdot \mathrm{ha}^{-1}\right)$} & \multicolumn{4}{|c|}{ Total plant fresh wt } & \multicolumn{4}{|c|}{ Total plant dry wt } \\
\hline & \multicolumn{2}{|c|}{$2017(\mathrm{~g})$} & \multicolumn{2}{|c|}{$2018(\mathrm{~g})$} & \multicolumn{2}{|c|}{$2017(\mathrm{~g})$} & \multicolumn{2}{|c|}{$2018(\mathrm{~g})$} \\
\hline & LT & Open & LT & Open & LT & $\overline{\text { Open }}$ & $\overline{\mathrm{LT}}$ & Open \\
\hline 0 & 1,235 & 845 & 943 & 614 & 143 & 98 & 96 & 59 \\
\hline 37 & 1,480 & 977 & 988 & 779 & 164 & 116 & 99 & 76 \\
\hline 74 & 1,599 & 1,078 & 1,146 & 781 & 189 & 126 & 118 & 79 \\
\hline 111 & 2,093 & 1,133 & 1,443 & 974 & 238 & 136 & 147 & 106 \\
\hline 148 & 2,068 & 1,218 & 1,375 & 778 & 230 & 141 & 129 & 80 \\
\hline 185 & 2,244 & 1,258 & 1,140 & 765 & 250 & 154 & 116 & 79 \\
\hline Regression $^{z}$ & $\mathrm{~L}^{* * *}$ & $\mathrm{~L}^{* * *}$ & $\mathrm{Q}^{* *}$ & $\mathrm{Q}^{* *}$ & $\mathrm{~L}^{* * *}$ & $\mathrm{~L} * * *$ & $\mathrm{Q}^{* *}$ & $\mathrm{Q}^{* * *}$ \\
\hline$r^{2}$ y & 0.59 & 0.46 & 0.39 & 0.41 & 0.59 & 0.53 & 0.37 & 0.46 \\
\hline PS mean & 1,787 & 1,085 & 1,173 & 782 & 202 & 128 & 118 & 80 \\
\hline \multicolumn{9}{|l|}{$P$ value } \\
\hline PS & \multicolumn{2}{|c|}{$<0.0001$} & \multicolumn{2}{|c|}{$<0.0001$} & \multicolumn{2}{|c|}{$<0.0001$} & \multicolumn{2}{|c|}{$<0.0001$} \\
\hline $\mathrm{N}$ rate $\mathrm{x}$ PS & \multicolumn{2}{|c|}{0.073} & \multicolumn{2}{|c|}{0.289} & \multicolumn{2}{|c|}{0.100} & \multicolumn{2}{|c|}{0.738} \\
\hline
\end{tabular}

${ }^{\mathrm{z}} \mathrm{L}=$ linear and $\mathrm{Q}=$ quadratic regression. $* *, * * *$ Significant at $P \leq 0.01$ or 0.001 , respectively.

${ }^{\mathrm{y}} r^{2}=$ coefficient of determination.

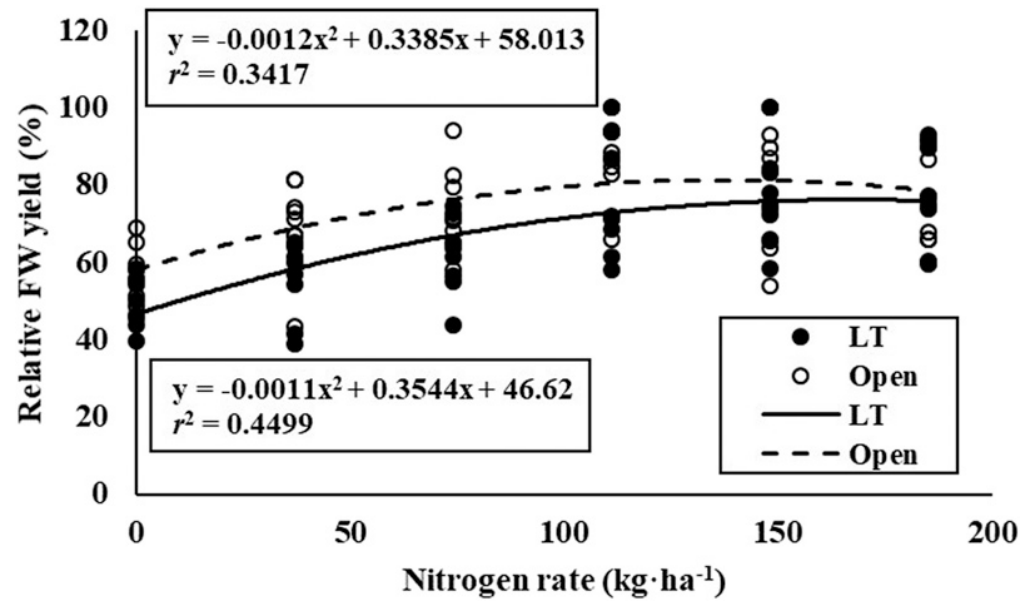

Fig. 4. Relative fresh weight (FW) yield of sweet basil grown under two production systems [low tunnel (LT) and open field (Open)] at increasing N application rates. Data points are actual values from 2017 and 2018. $r^{2}=$ coefficient of determination.

between 7.3 and $69.2 \mathrm{~g} \cdot \mathrm{g}^{-1} \mathrm{~N}$ applied in both years, and for DW NFUE ranged between 1.0 and $6.9 \mathrm{~g} \cdot \mathrm{g}^{-1} \mathrm{~N}$ applied. Under LT, FW and DW NFUE were $116 \%$ and $81 \%$ greater, respectively, than open field in 2017, but they were the same in 2018. In contrast, LT had no effect on ANRE, which ranged between $5.6 \%$ and $25.9 \% \mathrm{~N}$ uptake to $\mathrm{N}$ application rate. Similarly, $\mathrm{N}$ rate had no effect on NFUE (either for FW and DW) and on ANRE in 2017, but NFUE and ANRE decreased with $\mathrm{N}$ rate in 2018, as determined by ANOVA (Table 4). Despite the differences by ANOVA, regressions within the $\mathrm{N}$ rate interval were not significant and had low coefficient of determination $\left(r^{2}<0.25\right)$, likely to the increased variability as $\mathrm{N}$ rate decreased. In addition, data without $\mathrm{N}$ application could not be included because it is divided by 0 (no interception).

\section{Discussion}

LTs increased sweet basil vegetative growth and yield as measured by plant height, stem diameter, FW, and DW. This study supported previous work with specialty crops that reported an increase in vegetative growth and yield under rowcovers or LTs (Acharya et al., 2019; Arancibia and Motsenbocker, 2008; Gerber et al., 1988; Ibarra et al., 2001; Lamont, 2005; Nair and Ngouajio, 2010; Soltani et al., 1995). The overall increase in sweet basil production under LT was $58 \%$ and $53 \%$ for FW and DW, respectively. LTs are mostly used early in spring to protect against low temperatures, but the increased productivity of sweet basil throughout the summer indicates an additional benefit of using LTs. Increases in growth and production of cucumbers and sweet peppers under LT in a tropical environment despite the increased temperature have been reported (Arancibia, 2012). LTs create a greenhouse environment by increasing air temperature, reducing wind, and reducing solar radiation (shading), which results in less evapotranspiration and water stress (Acharya et al., 2019; Arancibia, 2019). This more favorable microenvironment has resulted in increased vegetative growth and yield of vegetable crops like cucumber, watermelon, and peppers (Arancibia, 2012; Arancibia and Motsenbocker, 2008; Gerber et al., 1988).

In general, $\mathrm{N}$ fertilization increased sweet basil yield in both LTs and open field. The relationships with $\mathrm{N}$ rate changed from linear for both LT and open field in 2017 to quadratic in 2018 (Table 1). When the relative yields in relation to the maximum yield were pooled together, the relationships for both LT and open field were quadratic (Fig. 4). These results are consistent with other studies in which basil responded positively to $\mathrm{N}$ fertilizer in open fields (Biesiada and Kuś, 2010; Bufalo et al., 2015; Sifola and Barbieri, 2006). Similar to our results, $N$ fertilizer improved fresh basil yield and aboveground DW but did not affect plant height (Sifola and Barbieri, 2006).

Based on the relative yield from both years, basil production under LT required $19 \%$ and $12 \%$ more $\mathrm{N}$ than in open field to optimize $\mathrm{N}$ fertilization for $\mathrm{FW}$ and $\mathrm{DW}$, respectively. This increase in optimum $\mathrm{N}$ rate indicates that the enhanced vegetative growth under LT benefited from additional $\mathrm{N}$ fertilization. The optimum $\mathrm{N}$ rate in this study for open field basil production, however, was $94 \%$ of the recommendation $\left(111 \mathrm{~kg} \cdot \mathrm{ha}^{-1}\right)$ in the southeastern United States (Kemble 2016). However, this is one local situation and there are more factors (e.g., economics, variability in responses, soil, local climatic conditions) involved in determining a recommendation (Hochmuth et al., 2017). Nevertheless, our results support the southeastern recommendation for open field conditions, but suggest that adjustments may be necessary under LTs.

Leaf and plant $\mathrm{N}$ concentration decreased under LTs in comparison with open field (Tables 2 and 3). One possible explanation is the dilution effect of $\mathrm{N}$ compounds in plant tissue due to faster and enhanced vegetative growth under LTs caused by more favorable microenvironment and increased heat index (Acharya et al., 2019; Arancibia, 2012; Nair and Ngouajio, 2010; Soltani et al., 1995). Lemaire and Gastal (1997) also concluded that leaf $\mathrm{N}$ concentration declines as plant growth increases. Another likely explanation is a reduced $\mathrm{N}$ uptake due to reduced evapotranspiration under LTs (Acharya et al., 2019; Arancibia, 2012). Reduced N flow is supported by reports indicating that shade decreases leaf $\mathrm{N}$ concentration (Lemaire and Gastal, 1997; Lemaire et al., 1991; Malagoli 
Table 2. Leaf $\mathrm{N}$ concentration in sweet basil grown under two production systems (PS) [low tunnel (LT) and open field (Open)] at increasing N applications rates.

\begin{tabular}{|c|c|c|c|c|c|c|c|c|c|c|c|c|}
\hline \multirow[b]{3}{*}{$\mathrm{N}$ rate $\left(\mathrm{kg} \cdot \mathrm{ha}^{-1}\right)$} & \multicolumn{6}{|c|}{2017} & \multicolumn{6}{|c|}{2018} \\
\hline & \multicolumn{2}{|c|}{$30 \mathrm{DAT}^{\mathrm{z}}(\%)^{\mathrm{y}}$} & \multicolumn{2}{|c|}{60 DAT $(\%)$} & \multicolumn{2}{|c|}{85 DAT $(\%)$} & \multicolumn{2}{|c|}{30 DAT (\%) } & \multicolumn{2}{|c|}{52 DAT $(\%)$} & \multicolumn{2}{|c|}{75 DAT $(\%)$} \\
\hline & LT & Open & LT & Open & $\mathrm{LT}$ & Open & LT & Open & $\mathrm{LT}$ & Open & LT & Open \\
\hline 0 & & & 2.7 & 3.5 & 2.3 & 2.6 & & & 4.1 & & 4.3 & \\
\hline 37 & & & 2.9 & 4.2 & 2.5 & 2.9 & & & 4.4 & & 4.0 & \\
\hline 74 & & & 3.2 & 4.2 & 2.8 & 3.4 & & & 4.3 & & 4.9 & \\
\hline 111 & & & 3.3 & 4.4 & 2.9 & 3.4 & & & 4.2 & & 4.8 & \\
\hline 148 & & & 3.3 & 4.3 & 3.4 & 3.5 & & & 4.9 & & 5.2 & \\
\hline 185 & & & 3.5 & 4.3 & 3.0 & 3.4 & & & 5.4 & & 4.8 & \\
\hline Regression $^{\mathrm{x}}$ & NS & NS & $\mathrm{L}^{* *}$ & $\mathrm{Q}^{* * *}$ & $\mathrm{Q}^{* * *}$ & $\mathrm{Q}^{* * *}$ & NS & NS & $\mathrm{L} * * *$ & NS & $\mathrm{L}^{*}$ & NS \\
\hline$r^{2 \mathrm{w}}$ & - & - & 0.37 & 0.66 & 0.60 & 0.53 & - & - & 0.40 & - & 0.25 & - \\
\hline PS mean & 4.0 & 5.0 & 3.2 & 4.1 & 2.8 & 3.2 & 4.7 & 6.1 & 4.6 & 5.0 & 4.7 & 5.5 \\
\hline \multicolumn{13}{|l|}{$P$ value } \\
\hline PS & \multicolumn{2}{|c|}{$<0.0001$} & \multicolumn{2}{|c|}{$<0.0001$} & \multicolumn{2}{|c|}{$<0.0001$} & \multicolumn{2}{|c|}{$<0.0001$} & \multicolumn{2}{|c|}{0.001} & \multicolumn{2}{|c|}{$<0.0001$} \\
\hline $\mathrm{N}$ rate $\times \mathrm{PS}$ & \multicolumn{2}{|c|}{0.597} & \multicolumn{2}{|c|}{0.194} & \multicolumn{2}{|c|}{0.631} & \multicolumn{2}{|c|}{0.590} & \multicolumn{2}{|c|}{0.071} & \multicolumn{2}{|c|}{0.053} \\
\hline
\end{tabular}

${ }^{\mathrm{z}} \mathrm{DAT}=$ days after transplanting.

${ }^{\mathrm{y}}$ Percent leaf $\mathrm{N}$ per leaf dry weight.

${ }^{\mathrm{x}} \mathrm{L}=$ linear and $\mathrm{Q}=$ quadratic regression. $\mathrm{NS}, *, * *, * *$ Nonsignificant or significant at $P \leq 0.05,0.01$, or 0.001 , respectively.

${ }^{\mathrm{w}} r^{2}=$ coefficient of determination.

Table 3. Plant $\mathrm{N}$ concentration and total plant $\mathrm{N}$ uptake in sweet basil grown under two production systems (PS) [low tunnel (LT) and open field (Open)] at increasing $\mathrm{N}$ application rates.

\begin{tabular}{|c|c|c|c|c|c|c|c|c|}
\hline \multirow{3}{*}{$\begin{array}{l}\mathrm{N} \text { rate } \\
\left(\mathrm{kg} \cdot \mathrm{ha}^{-1}\right)\end{array}$} & \multicolumn{4}{|c|}{ Plant N concn } & \multicolumn{4}{|c|}{ Plant N uptake } \\
\hline & \multicolumn{2}{|c|}{$2017(\%)^{z}$} & \multicolumn{2}{|c|}{$2018(\%)$} & \multicolumn{2}{|c|}{$2017(\mathrm{~g})$} & \multicolumn{2}{|c|}{$2018(\mathrm{~g})$} \\
\hline & $\mathrm{LT}$ & $\overline{\text { Open }}$ & $\overline{\mathrm{LT}}$ & $\overline{\text { Open }}$ & $\mathrm{LT}$ & $\overline{\text { Open }}$ & LT & $\overline{\text { Open }}$ \\
\hline 0 & 3.4 & 3.7 & & & 4.3 & 3.0 & 4.3 & 3.2 \\
\hline 37 & 3.3 & 3.8 & & & 4.6 & 3.8 & 4.8 & 4.2 \\
\hline 74 & 3.5 & 4.1 & & & 6.1 & 4.6 & 5.8 & 4.5 \\
\hline 111 & 3.6 & 4.1 & & & 7.9 & 5.1 & 7.5 & 6.0 \\
\hline 148 & 3.9 & 4.2 & & & 8.5 & 5.5 & 6.9 & 4.6 \\
\hline 185 & 3.7 & 4.3 & & & 8.7 & 6.1 & 6.2 & 4.4 \\
\hline Regression $^{\mathrm{y}}$ & $\mathrm{L}^{* *}$ & $\mathrm{~L} * * *$ & NS & NS & $\mathrm{L} * * *$ & $\mathrm{~L} * * *$ & $\mathrm{Q}^{* * *}$ & $\mathrm{Q}^{* * *}$ \\
\hline$r^{2} \times$ & 0.30 & 0.43 & - & - & 0.70 & 0.72 & 0.52 & 0.51 \\
\hline $\begin{array}{l}\text { PS mean } \\
P \text { value }\end{array}$ & 3.6 & 4.1 & 5.1 & 5.8 & 6.7 & 4.7 & 5.9 & 4.5 \\
\hline PS & \multicolumn{2}{|c|}{$<0.0001$} & \multicolumn{2}{|c|}{$<0.0001$} & \multicolumn{2}{|c|}{$<0.0001$} & \multicolumn{2}{|c|}{$<0.0001$} \\
\hline $\mathrm{N}$ rate $\times \mathrm{PS}$ & \multicolumn{2}{|c|}{0.719} & \multicolumn{2}{|c|}{0.040} & \multicolumn{2}{|c|}{0.076} & \multicolumn{2}{|c|}{0.322} \\
\hline
\end{tabular}

${ }^{\mathrm{z}}$ Percent Plant $\mathrm{N}$ per plant dry weight

${ }^{\mathrm{y}} \mathrm{L}=$ linear and $\mathrm{Q}=$ quadratic regression. $\mathrm{NS},{ }^{* *}, * * *$ Nonsignificant or significant at $P \leq 0.01$ or 0.001 , respectively.

$\mathrm{x} r^{2}=$ coefficient of determination.

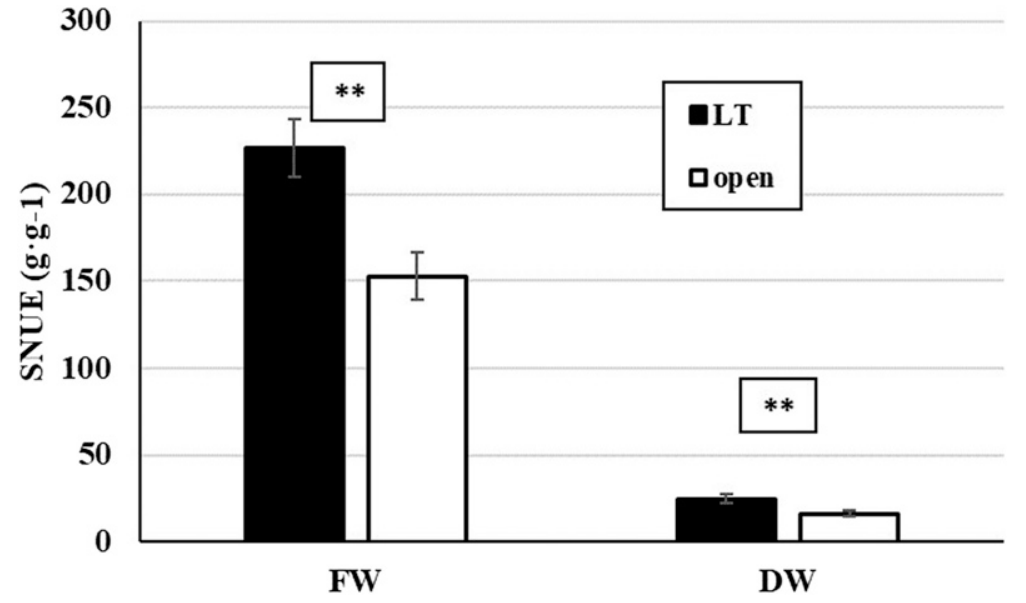

Fig. 5. Soil available nitrogen use efficiency (SNUE) without $\mathrm{N}$ fertilization (control) for fresh weight (FW) and dry weight (DW) in sweet basil grown under two production systems [low tunnel (LT) and open field (Open)]. Means are from 2-year data $(\mathrm{n}=8)$. Bars in each column are the SE. **Significantly different by least significant difference at $P<0.01$.

et al., 2005). Hence, both the dilution effect and decreased vascular flow may reduce $\mathrm{N}$ concentration in plant tissue under LT. Furthermore, optimum leaf $\mathrm{N}$ content in basil ranges from $4 \%$ to $6 \%$ (Bryson et al., 2014). In our study, leaf $\mathrm{N}$ concentrations were within the optimum range for both LT and open field in the first harvests in 2017 and in all harvests in 2018 , but were below optimum in the second and third harvests under LT in 2017. These results suggest that recommended nutrient concentrations in leaf/plant tissue for crops grown under LTs may need revision. Alternatively, adjusting $\mathrm{N}$ fertilization for LT production should be considered to avoid potential deficiencies.

The increase in leaf and plant $\mathrm{N}$ concentration in response to increasing $\mathrm{N}$ fertilization was inconsistent (Tables 2 and 3). Plant $\mathrm{N}$ concentration did not respond to increasing $\mathrm{N}$ rate in 2018. In the case of leaf $\mathrm{N}$ concentration, lack of response during first harvest was likely due to sufficient $\mathrm{N}$ already in the soil and/or greenhouse plug transplants for initial plant growth. By midseason, the response to $\mathrm{N}$ fertilizer applications was likely due to depletion of residual $\mathrm{N}$ in the control plots and/or transplants.

LTs increased total plant $\mathrm{N}$ uptake (Table 3). Enhanced vegetative growth under LT led to more aboveground DW and therefore total plant $\mathrm{N}$ uptake in spite of having less plant $\mathrm{N}$ concentration across harvests. Nitrogen application rate also influenced total plant $\mathrm{N}$ uptake (Table 3 ). In addition, the patterns of the combined $\mathrm{N}$ uptake in relation to $\mathrm{N}$ rate are similar to the yields of fresh and dry sweet basil (Table 1). Therefore, these results suggest that additional $\mathrm{N}$ is necessary to support the enhanced vegetative growth under LT, which also supports the higher 
Table 4. Nitrogen fertilizer use efficiency (NFUE) and apparent nitrogen recovery efficiency (ANRE) in sweet basil grown under two production systems (PS) [low tunnel (LT) and open field (Open)] at increasing $\mathrm{N}$ application rates.

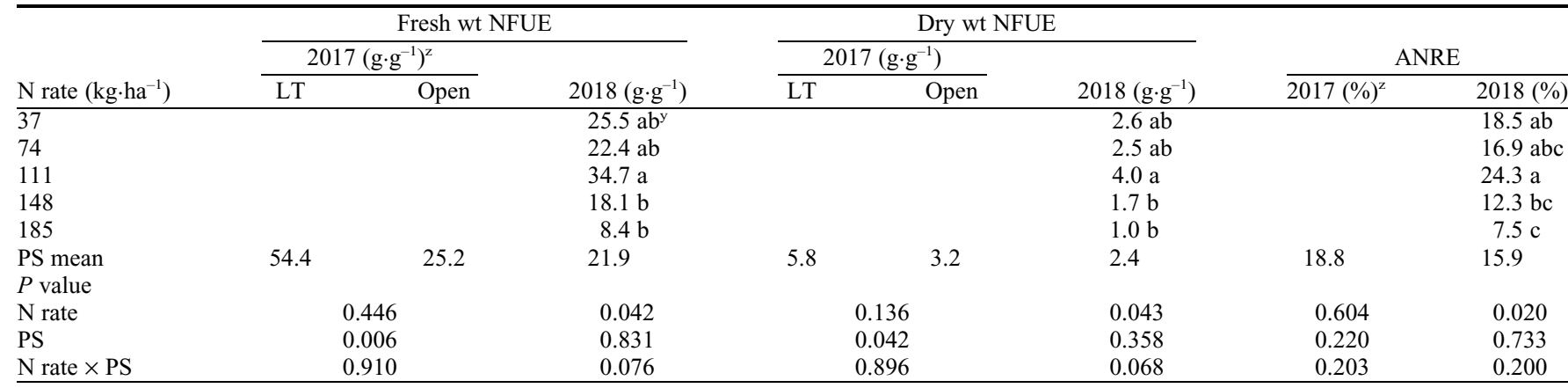

${ }^{\mathrm{z}}$ Fresh and dry weight per $\mathrm{N}$ application; percent plant $\mathrm{N}$ uptake per $\mathrm{N}$ application.

${ }^{\mathrm{y}}$ Means within each column followed by different letters are significantly different from each other by Fisher's least significant difference at $P \leq 0.05$.

optimum $\mathrm{N}$ rate for basil grown under LT than open field (Fig. 4).

Low tunnels improved SNUE under LTs when $\mathrm{N}$ fertilizer was not added (Fig. 5). Many studies have reported that LTs/rowcovers enhance vegetative growth (Acharya et al., 2019; Arancibia and Motsenbocker, 2008; Ibarra et al., 2001; Nair and Ngouajio, 2010; Soltani et al., 1995; Tillman et al., 2015). An increase in SNUE would be expected from these studies, but so far this is the first report, to our knowledge, indicating that SNUE increases in crops grown under LTs. Nevertheless, attention to fertilization is critical under LTs to avoid possible deficiencies, because the $\mathrm{N}$ concentration in the tissue decreased and total $\mathrm{N}$ uptake increased.

The results on NFUE under LTs and in response to $\mathrm{N}$ fertilization were inconsistent (Table 4). The relatively large yield of fresh and dry basil without $\mathrm{N}$ application (control) under LTs in 2018; which was subtracted from the yield at each $\mathrm{N}$ application rate, reduced the relative yield increase that was used to determine NFUE. The small difference between LT and open field may have obscured any increase in NFUE. Therefore, this study partially supports the hypothesis that LTs would increase NFUE in sweet basil production. Similarly, the reduction in NFUE with increasing $\mathrm{N}$ fertilization in 2018 only also supports partially the reports from studies with wheat and rice (Gauer et al., 1992; Ye et al., 2007). Therefore, NFUE is influenced by both plant $\mathrm{N}$ demand and $\mathrm{N}$ applications (Šturm et al., 2010).

In contrast, ANRE was not influenced by LT, but the response to $\mathrm{N}$ fertilization was also inconsistent in this study with sweet basil (Table 4). There was no difference in 2017, but as expected, ANRE decreased at higher $\mathrm{N}$ rate in 2018. The relative increase in yield by additional $\mathrm{N}$ is divided by a larger $\mathrm{N}$ rate. Therefore, our results could not support a report indicating that ANRE increases with increasing $\mathrm{N}$ rate in sandy soil for rice production (Ye et al., 2007).

\section{Conclusion}

This study showed the potential of using LTs throughout the summer to enhance vegetative growth and yield of specialty crops.
Adjusting fertilization may be necessary to optimize inputs and yield because optimum $\mathrm{N}$ rate increased under $\mathrm{LT}$ in comparison with open field production. This was supported by the yield increase with $\mathrm{N}$ rate and the total $\mathrm{N}$ uptake in both years. The reduced $\mathrm{N}$ concentration in plant tissue under LT warrants studies to confirm or adjust recommended nutrient levels because potential deficiencies may appear. SNUE increased under LTs, which may result in improved sustainability. In contrast, there were inconsistent increases in NFUE, and ANRE did not change with LTs. In conclusion, LTs and rowcovers are additional management tools that can increase yield and land productivity in small operations.

\section{Literature Cited}

Acharya, T.P., G.E. Welbaum, and R.A. Arancibia. 2019. Low tunnels reduce irrigation water needs and increase growth, yield and water use efficiency in Brussels sprouts. HortScience 54:470-475.

Arancibia, R.A. 2012. Rowcovers in vegetable crops production in tropical and temperate climates. HortScience 47:S107-S108 (abstr.).

Arancibia, R.A. 2019. Low tunnels benefits and opportunities for specialty crops in Missouri. Missouri Produce Growers bulletin. 8 Apr. 2019. <https://ipm.missouri.edu/MPG/2019/4/ lowTunnel/>.

Arancibia, R.A. and C.E. Motsenbocker. 2008. Differential watermelon fruit size distribution in response to plastic mulch and spunbonded polyester rowcover. HortTechnology 18:45-52.

Biesiada, A. and A. Kuś. 2010. The effect of nitrogen fertilization and irrigation on yielding and nutritional status of sweet basil (Ocimum basilicum L.). Acta Sci. Pol. Hortorum Cultus 9:3-12.

Bremner, J.M. 1996. Nitrogen - Total, p. 10851121. In: D.L. Sparks (ed.). Methods of soil analysis: Part 3. Soil Sci. Soc. Amer., Amer. Soc. Agron., Madison, WI.

Bryson, G.M., H.A. Mills, D.N. Sasseville, J.B Jones, and A.V. Barker. 2014. Crop nutritional table, p. 267-478. Plant Analysis Handbook III: A guide to sampling, preparation, analysis, interpretation and use of results of agronomic and horticultural crop plant tissue. Micro-Macro Publishing, Incorporated, Athens, GA.

Bufalo, J., C.L. Cantrell, T. Astatkie, V.D. Zheljazkov, A. Gawde, and C.S.F. Boaro.
2015. Organic versus conventional fertilization effects on sweet basil (Ocimum basilicum L.) growth in a greenhouse system. Ind. Crops Prod. 74:249-254.

DeKalb, C.D., B.A. Kahn, B.L. Dunn, M.E. Payton, and A.V. Barker. 2014. Substitution of a soilless medium with yard waste compost for basil transplant production. HortTechnology 24:668-675.

Dhakal, C., K. Lange, M.N. Parajuli, and E. Segarra. 2019. Dynamic optimization of nitrogen in plateau cotton yield function with nitrogen carryover considerations. J. Agr. Appl. Econ. 51:1-17.

Fleming, C.S., M.S. Reiter, J.H. Freeman, and R. Maguire. 2013. Optimizing irrigation of fresh market tomato grown in the Mid-Atlantic United States. HortTechnology 23:859-867.

Gai, X., H. Liu, L. Zhai, G. Tan, J. Liu, T. Ren, and H. Wang. 2016. Vegetable yields and soil biochemical properties as influenced by fertilization in Southern China. Appl. Soil Ecol. 107:170-181.

Gauer, L., C. Grant, L. Bailey, and D. Gehl. 1992. Effects of nitrogen fertilization on grain protein content, nitrogen uptake, and nitrogen use efficiency of six spring wheat (Triticum aestivum $\mathrm{L}$.) cultivars, in relation to estimated moisture supply. Can. J. Plant Sci. 72:235-241.

Gerber, J.M., I. Mohd-Khir, and W.E. Splittstoesser. 1988. Row tunnel effects on growth, yield and fruit quality of bell pepper. Scientia Hort. 36:191-197.

Hirel, B., J. Le Gouis, B. Ney, and A. Gallais. 2007. The challenge of improving nitrogen use efficiency in crop plants: Towards a more central role for genetic variability and quantitative genetics within integrated approaches. J. Expt. Bot. 58:2369-2387.

Hochmuth, G., E. Hanlon, and A. Overman. 2017. Fertilizer experimentation, data analyses, and interpretation for developing fertilization recommendations - examples with vegetable crop research. UF/IFAS Extension publication SL345. University of Florida Institute of Food and Agricultural Sciences. 5 Nov. 2019. <https://edis.ifas.ufl.edu/ss548>.

Ibarra, L., J. Flores, and J.C. Dì̀az-Pérez. 2001. Growth and yield of muskmelon in response to plastic mulch and row covers. Scientia Hort. 87:139-145.

Kemble, J.M. 2016. Southeastern U.S. vegetable crop handbook. Southeastern Vegetable Extension Workers. 22 Dec. 2016. <https://pubs.ext. vt.edu/AREC/AREC-66/AREC-66.html $>$.

Lamont, W.J. 2005. Plastics: Modifying the microclimate for the production of vegetable crops. HortTechnology 15:477-481. 
Lemaire, G. and F. Gastal. 1997. Chapter 1. N uptake and distribution in plant canopies, p. 3 43. In: G. Lemaire (ed.). Diagnosis of the nitrogen status in crops. Springer Verlag, NY.

Lemaire, G. and F. Gastal. 2009. Quantifying crop responses to nitrogen deficiency and avenues to improve nitrogen use efficiency, p. 171-211. In: V. Sadras and D. Calderini (eds.). Crop physiology: Applications for genetic improvement and agronomy. 2nd ed. Academic Press, San Diego, CA.

Lemaire, G., B. Onillon, G. Gosse, M. Chartier, and J. Allirand. 1991. Nitrogen distribution within a lucerne canopy during regrowth: Relation with light distribution. Ann. Bot. 68:483-488.

Malagoli, P., P. Laine, L. Rossato, and A. Ourry. 2005. Dynamics of nitrogen uptake and mobilization in field-grown winter oilseed rape (Brassica napus) from stem extension to harvest: I. Global N flows between vegetative and reproductive tissues in relation to leaf fall and their residual N. Ann. Bot. 95:853-861.

Nair, A. and M. Ngouajio. 2010. Integrating rowcovers and soil amendments for organic cucumber production: Implications on crop growth, yield, and microclimate. HortScience 45:566-574.

Sifola, M.I. and G. Barbieri. 2006. Growth, yield and essential oil content of three cultivars of basil grown under different levels of nitrogen in the field. Scientia Hort. 108:408-413.

Simon, J.E., J. Quinn, and R.G. Murray. 1990.

Basil: A source of essential oils, 484-489. In: J. Janick and J.E. Simon (eds.). Advances in new crops. Timber Press, Portland, OR.

Soltani, N., J.L. Anderson, and A.R. Hamson. 1995. Growth analysis of watermelon plants grown with mulches and rowcovers. J. Amer. Soc. Hort. Sci. 120:1001-1009.

Stenberg, M., H. Aronsson, B. Lindén, T. Rydberg, and A. Gustafson. 1999. Soil mineral nitrogen and nitrate leaching losses in soil tillage systems combined with a catch crop. Soil Tillage Res. 50:115-125.

Šturm, M., N. Kacjan-Maršić, V. Zupanc, B. BračičŽeleznik, S. Lojen, and M. Pintar. 2010. Effect of different fertilisation and irrigation practices on yield, nitrogen uptake and fertiliser use efficiency of white cabbage (Brassica oleracea var. capitata L.). Scientia Hort. 125:103-109.

Sutton, M.A., A. Bleeker, C. Howard, M. Bekunda, B. Grizzetti, W. De Vries, H. Van Grinsven, Y. Abrol, T. Adhya, and G. Billen. 2013. Our Nutrient World: The challenge to produce more food and energy with less pollution. NERC Centre for Ecol. \& Hydrology, Edinburgh, UK. Tamang, B.G., K.G. Brasier, W.E. Thomason, C.A. Griffey, and T. Fukao. 2017. Differential responses of grain yield, grain protein, and their associated traits to nitrogen supply in soft red winter wheat. J. Plant Nutr. Soil Sci. 180:316-325.

Tillman, J., A. Nair, M. Gleason, and J. Batzer. 2015. Evaluating strip tillage and rowcover use in organic and conventional muskmelon production. HortTechnology 25:487-495.

Wyenandt, C.A. 2016. Mid-Atlantic commercial vegetables production recommendation. Virginia Coop. Ext. Virginia Tech. Virginia State Univ. 25 Dec. 2016. VCE Pub. 456-420. <http:/ pubs.ext.vt.edu/456/456-420/456-420.html>.

Wyenandt, C.A., J.E. Simon, R.M. Pyne, K. Homa, M.T. McGrath, S. Zhang, R.N. Raid, L.-J. Ma, R. Wick, and L. Guo. 2015. Basil downy mildew (Peronospora belbahrii): Discoveries and challenges relative to its control. Phytopathology 105:885-894.

Ye, Q., H. Zhang, H. Wei, Y. Zhang, B. Wang, K. Xia, Z. Huo, Q. Dai, and K. Xu. 2007. Effects of nitrogen fertilizer on nitrogen use efficiency and yield of rice under different soil conditions. Front. Agr. China 1:30-36.

Zotarelli, L., M. Dukes, J. Scholberg, R. MunozCarpena, and J. Icerman. 2009. Tomato nitrogen accumulation and fertilizer use efficiency on a sandy soil, as affected by nitrogen rate and irrigation scheduling. Agr. Water Mgt. 96:1247-1258. 